J. Braz. Chem. Soc., Vol. 16, No. 3B, 634-638, 2005.

Printed in Brazil - (O2005 Sociedade Brasileira de Química

$0103-5053 \$ 6.00+0.00$

\title{
Others Flavonoids from Ouratea hexasperma (Ochnaceae)
}

\author{
Juliana F. de S. Daniel ${ }^{a}$, Mário Geraldo de Carvalho ${ }^{*, a}$, Renata da S. Cardoso ${ }^{a}$, Maria de F. Agra ${ }^{b}$ \\ and Marcos N. Eberlin
}

\author{
${ }^{a}$ Departamento de Química, Instituto de Ciências Exatas, Universidade Federal Rural do Rio de Janeiro, \\ Br 465 Km. 7, 23851-970 Seropédica - RJ, Brazil \\ ${ }^{b}$ Centro de Ciências da Saúde, LTF, Universidade Federal da Paraíba, 58051-970 João Pessoa -PB, Brazil \\ ${ }^{c}$ Instituto de Química, Universidade Estadual de Campinas, 13083-970 Campinas - SP, Brazil
}

\begin{abstract}
O fracionamento cromatográfico dos extratos das folhas de Ouratea hexasperma (Ochnaceae) forneceu, além do novo biflavonóide 5-hidróxi-7-metoxiflavona-(4'-O-8")-5",4"'-diidróxi-7"'metoxiflavona, a agathisflavona, 7"-metilagathisflavona, epicatequina, 6-C-glicopiranosil-luteolina e a 3-O-glicopiranosil-quercetina já registradas na literatura. As estruturas desses compostos foram estabelecidas através da análise dos dados espectrométricos de IV, EM e RMN.
\end{abstract}

Chromatographic fractionation of the extracts from the leaves of Ouratea hexasperma (Ochnaceae) afforded a new flavone dimer 5-hydroxy-7-methoxyflavone-(4'-O-8”)-5",4"'dihydroxy-7"'-methoxyflavone besides known agathisflavone, 7'-methylagathisflavone, epicatechin, 6-C-glycopyranosyl-luteolin and 3-O-glycopyranosyl-quercetin. The IR, NMR and mass spectra data analyses were used to establish the structures of these compounds.

Keywords: Ouratea hexasperma, Ochnaceae, flavone dimer, agathisflavone, lanaraflavone

\section{Introduction}

The genus Ouratea (Ochnaceae) comprises 300 tropical species occurring mainly in South America, ${ }^{1}$ and has been reported to be used in folk medicine for the treatment of rheumatic and gastric distress. In previous reports we described the phytochemical study of species from the Ochnaceae including Luxemburgia ${ }^{2-4}$ and Ouratea $^{5-8}$ genera. We have also isolated biisoflavonoids ${ }^{9}$ and a flavone dimer from Ouratea hexasperma collected in Amazon cerrado. ${ }^{10}$ In further investigations, we have also detected cytotoxic and antitumour activities ${ }^{11,12}$ and DNA topoisomerase inhibition ${ }^{12}$ by biflavonoids from those species. Besides the biflavonoids as phytochemical constituents, it was found other farmacological activities of Ouratea species. ${ }^{13-15}$ The present paper describes the isolation of a new biflavonoid, its acetyl and pentamethyl derivatives, besides the first identification of known flavonoids, agathisflavone, epicatechin, 6-Cglycopyranosyl-luteolin and 3-O-glycopyranosylquercetin in $O$. hexasperma. The significant amount of

* e-mail: mgeraldo@ufrrj.br 7"-methylagathisflavone from the leaves of Ouratea hexasperma collected in Amazon cerrado ${ }^{10}$ was confirmed in this species of Mata Atlântica. The spectral data, including 1D and 2D NMR experiments of the natural substances and of the derivatives were used to establish the structures and the unambiguous ${ }^{1} \mathrm{H}$ and ${ }^{13} \mathrm{C}$ NMR assignments.

\section{Experimental}

\section{General procedures}

Melting points are uncorrected. IR spectra were recorded on a Perkin-Elmer 1605 FT-IT spectrophotometer using $\mathrm{KBr}$ discs or $\mathrm{NaCl}$ film. ${ }^{1} \mathrm{H}(200.0 \mathrm{MHz})$ and ${ }^{13} \mathrm{C}$ (50.3 MHz) NMR spectra recorded on a Bruker AC 200 spectrometer using $\mathrm{D}_{3} \mathrm{CSOCD}_{3}, \mathrm{D}_{3} \mathrm{CCOCD}_{3}$ or $\mathrm{CDCl}_{3}$ and TMS as internal standard. HRESIMS were obtained with a VG 7070E-HF spectrometer using (methanol: $\mathrm{H}_{2} \mathrm{O}$, Ar as CAD), CE $20 \mathrm{eV}$ for MS and $45 \mathrm{eV}$ for MS-MS) in negative mode for $\mathbf{1}$ and (methanol: $\mathrm{H}_{2} \mathrm{O}$ ) + formic acid in positive mode for 1a. HPLC analysis was performed using a LC6AD Shimadzu isocratic pump. Analyses were carried out in $5 \mathrm{~mm}$ Betasil $\mathrm{C}_{18}$ preparative column $250 \mathrm{~mm}$ x $20 \mathrm{~mm}$, 
using a mixture of methanol/water (6:4) as mobile phase, the eluted fraction at $3 \mathrm{~mL} \mathrm{~min}^{-1}(1.0 \mathrm{~mL}$ injection volume) yielded a glycoside mixture. Column chromatography with silica gel (Merck and Aldrich 0.05-0.20 mm); TLC: silica gel $\mathrm{H}$ and $\mathrm{G}$ (Merck and Aldrich) were used to analyze the fractions collected from column chromatography (CC) with visualization by $\mathrm{UV}$ (254 and $366 \mathrm{~nm}$ ), $\mathrm{AlCl}_{3}-\mathrm{EtOH}(1 \%)$ or exposure to iodine vapor.

\section{Plant material}

The leaves of Ouratea hexasperma St.-Hil (Ochnaceae) were collected in João Pessoa, Paraíba State, Brazil, in October 2002. Voucher specimen ( $\mathrm{N}^{\circ} \mathrm{JPB}-21438$ ) is deposited at the Herbarium Prof. Lauro Pires Xavier Universidade Federal da Paraíba, João Pessoa-PB, Brazil.

\section{Extraction and isolation}

Air dried leaves of $O$. hexasperma $(585.0 \mathrm{~g})$ were extracted exhaustively with $\mathrm{CH}_{2} \mathrm{Cl}_{2}$ and $\mathrm{MeOH}$ at room temperature. The solvents were removed under vacuum to yield residues LD (14.52 g) and LM (133.0 g). The LD residue (13.5 g) was filtered on a silica gel column using $\mathrm{CH}_{2} \mathrm{Cl}_{2}$, EtOAc and $\mathrm{MeOH}$. The fraction eluted with $\mathrm{CH}_{2} \mathrm{Cl}_{2}$ (LDD, $7.5 \mathrm{~g}$ ) was analyzed by TLC, IR and ${ }^{1} \mathrm{H}$ NMR and a mixture of aliphatic alcohols was identified. The fraction eluted with EtOAc (LDA, $4.0 \mathrm{~g}$ ) was crystallized from $\mathrm{MeOH}$ to afford 7,7"-O-dimethyllanaraflavone (1, mp 325-328 ${ }^{\circ} \mathrm{C}$, $98.2 \mathrm{mg}$ ). The methanolic extract (LM, $133.8 \mathrm{~g}$ ) was partitioned with hexane:diethyl ether 1:1, EtOAc and $\mathrm{MeOH}$. The hexane-ether residue (LMH, $4.53 \mathrm{~g}$ ) was dissolved in acetone and filtered on a sephadex LH-20 column, eluted with $\mathrm{MeOH}$, to give 7'-O-methylagathisflavone $(\mathbf{2}, 217.0 \mathrm{mg})$, agathisflavone $(\mathbf{3}, 13.3 \mathrm{mg})$ and epicatechin (30.0 mg). The EtOAc residue (LMA, 52.2 g) was chromatographed on a silica gel column, using mixtures of chloroform and methanol, increasing the polarity to $100 \%$ methanol, to give 90 fractions. Fractions 28-31 yielded 7'-Omethylagathisflavone (2, 1.2 g). Fraction 53-70 (400.0 mg) were chromatographed on a silica gel column and eluted on a $\mathrm{C}_{18}$ HPLC preparative column (using a ShimadzuLC-6AD isocratic pump) to yield a mixture of 6-C-glycopyranosylluteolin and 3-O-glycopyranosyl-quercetin (30.0 mg).

\section{7,7”-O-dimethyllanaraflavone, (1), $\mathrm{C}_{32} \mathrm{H}_{22} \mathrm{O}_{10}$}

Yellow crystals, $\mathrm{mp} 325-328^{\circ} \mathrm{C}$ (methanol). HRESIMS/ MS: $693.1554\left[\mathrm{M}^{+\bullet}+1,70 \%\left(\mathrm{C}_{38} \mathrm{H}_{22} \mathrm{O}_{13}+\mathrm{H}^{+}\right)\right], 443$ (55), 401 (40), 361 (80) and 301 (95), (Scheme 1). ${ }^{1} \mathrm{H}$ and ${ }^{13} \mathrm{C}$ NMR: (Table 1).

\section{7,7”-O-dimethyl-5,5”,4”-triacetyllanaraflavone, (1a)}

7,7"-O-dimethyllanaroflavone $(\mathbf{1}, 33.0 \mathrm{mg})$ was dissolved in pyridine $(2.0 \mathrm{~mL})$ and $\mathrm{Ac}_{2} \mathrm{O}(2 \mathrm{~mL})$. The solution was allowed to stand for $24 \mathrm{~h}$ at room temperature. The usual work-up afforded a residue which was crystallized from $\mathrm{MeOH}$ to give the triacetyl derivative 1a (mp 125-130 ${ }^{\circ} \mathrm{C}, 20.6 \mathrm{mg}$ ). ${ }^{1} \mathrm{H}$ and ${ }^{13} \mathrm{C}$ NMR: (Table 1).

Lanaraflavone-pentamethyl ether, (1b)

Compound 1 (20.0 mg), $\mathrm{Me}_{2} \mathrm{SO}_{4}(0.19 \mathrm{~mL})$, dry $\mathrm{Me}_{2} \mathrm{CO}$ $(2.0 \mathrm{~mL})$ and $\mathrm{K}_{2} \mathrm{CO}_{3}(0.2 \mathrm{~g})$ were heated under reflux for $2 \mathrm{~h}$. After removal of the inorganic salts with $\mathrm{H}_{2} \mathrm{O}$, the solution was dried over $\mathrm{Na}_{2} \mathrm{SO}_{4}$ and concentrated to dryness. The crude residue was subjected to silica gel column, eluting with $\mathrm{CHCl}_{3}$ to give the penta- $O$-methyl derivative $\mathbf{1 b}$ (mp $265{ }^{\circ} \mathrm{C}, 12.0 \mathrm{mg}$ ). $\mathrm{H}^{1} \mathrm{NMR}$ data: ${ }^{16},{ }^{13} \mathrm{C}$ NMR: (Table 1).

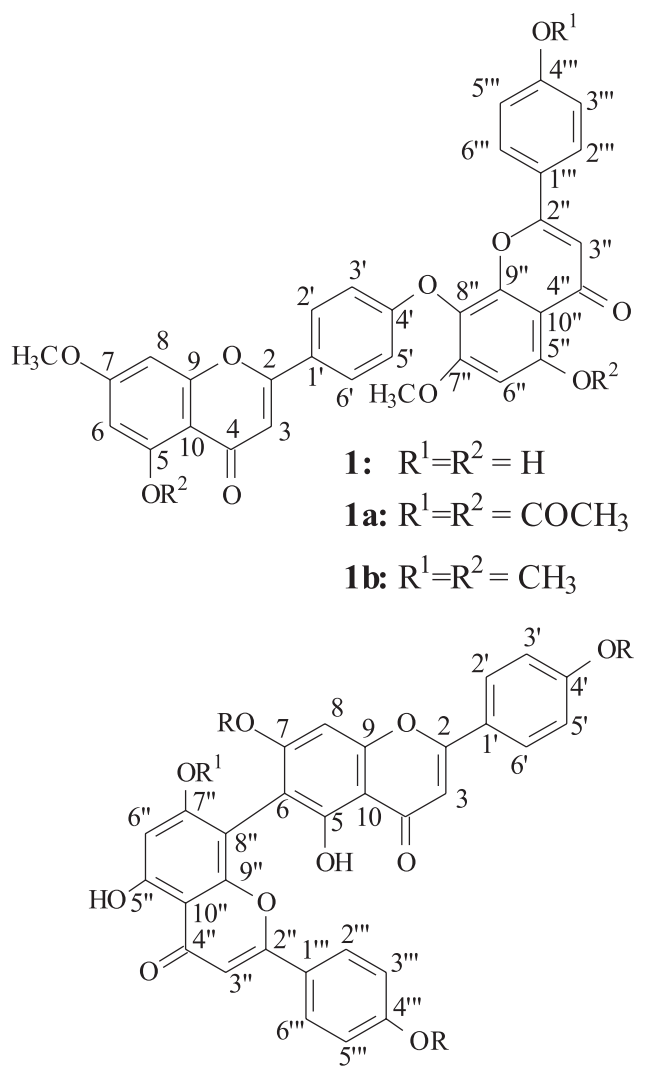

$$
\begin{aligned}
& \text { 2: } \mathrm{R}=\mathrm{H}, \mathrm{R}^{1}=\mathrm{CH}_{3} \\
& \text { 2a: } \mathrm{R}=\mathrm{R}^{1}=\mathrm{CH}_{3} \\
& \text { 3: } \mathrm{R}=\mathrm{R}^{1}=\mathrm{H}
\end{aligned}
$$

\section{Results and Discussion}

7"-O-methylagathisflavone (2), agathisflavone (3), epicatechin and the mixture of 6-C-glycopyranosyl- 
Table 1. ${ }^{1} \mathrm{H}(200 \mathrm{MHz})$ and ${ }^{13} \mathrm{C}(50.3 \mathrm{MHz}) \mathrm{NMR}$ data for $\mathbf{1}\left(\mathrm{D}_{3} \mathrm{CSOCD}_{3}\right)$, 1a and $\mathbf{1 b}\left(\mathrm{CDCl}_{3}\right)$

\begin{tabular}{|c|c|c|c|c|c|}
\hline \multirow[b]{2}{*}{$\mathrm{C}$} & \multicolumn{2}{|c|}{1} & \multicolumn{2}{|c|}{$1 \mathbf{a}$} & \multirow{2}{*}{$\frac{\mathbf{1 b}}{\delta_{\mathrm{C}}}$} \\
\hline & $\delta \mathrm{C}$ & $\delta_{\mathrm{H}}(\text { mult, } \mathrm{Hz})^{\mathrm{a}}$ & $\delta_{\mathrm{C}}$ & $\delta_{\mathrm{H}}\left(\right.$ mult, Hz) ${ }^{\mathrm{a}}$ & \\
\hline 2 & 163.3 & - & 163.5 & - & 163.0 \\
\hline 4 & 182.0 & - & 176.2 & - & 177.4 \\
\hline 5 & 161.4 & - & 158.8 & - & 166.2 \\
\hline 7 & 165.3 & - & 163.5 & - & 164.0 \\
\hline 9 & 158.4 & - & 160.4 & - & 157.9 \\
\hline 10 & 104.2 & - & 109.1 & - & 108.1 \\
\hline 1 & 124.7 & - & 128.4 & - & 125.5 \\
\hline 4 & 161.4 & - & 161.2 & - & 160.9 \\
\hline $2 "$ & 163.8 & - & 161.5 & - & 160.7 \\
\hline $4 "$ & 182.0 & - & 176.5 & - & 177.4 \\
\hline $5 "$ & 157.9 & - & 153.2 & - & 162.2 \\
\hline $7 "$ & 157.3 & - & 150.5 & - & 156.3 \\
\hline $8 "$ & 120.7 & - & 125.5 & - & 123.2 \\
\hline $9 "$ & 148.3 & - & 147.2 & - & 146.8 \\
\hline $10 "$ & 103.0 & - & 107.9 & - & 107.3 \\
\hline $1 " '$ & 121.7 & - & 125.8 & - & 124.0 \\
\hline 4"' & 161.3 & - & 156.1 & - & 166.1 \\
\hline $\mathrm{H}_{3} \mathrm{C} \underline{\mathrm{CO}}-4$ ““” & - & - & 168.9 & - & \\
\hline $\mathrm{H}_{3} \mathrm{CC} \mathrm{C}-5,5$ & - & - & $169.70 \times 2$ & - & \\
\hline \multicolumn{6}{|l|}{$\mathrm{CH}$} \\
\hline 3 & 104.8 & $6.85(\mathrm{~s})$ & 108.3 & $6.52(\mathrm{~s})$ & 108.1 \\
\hline 6 & 98.1 & $6.35(\mathrm{~d}, 2.0)$ & 107.6 & $6.59(\mathrm{~d}, 2.4)$ & 96.1 \\
\hline 8 & 92.8 & $6.76(\mathrm{~d}, 2.0)$ & 99.07 & $6.84(\mathrm{~d}, 2.4)$ & 92.8 \\
\hline $2^{\prime}, 6^{\prime}$ & 128.3 & $8.06(\mathrm{~d}, 8.0)$ & 127.3 & $7.82(\mathrm{~d}, 8.8)$ & 127.5 \\
\hline 3,5 & 115.6 & $7.17(\mathrm{~d}, 8.0)$ & 115.6 & $7.09(\mathrm{~d}, 8.8)$ & 114.4 \\
\hline $3 "$ & 104.2 & $6.94(\mathrm{~s})$ & 107.9 & $6.54(\mathrm{~s})$ & 107.1 \\
\hline $6 "$ & 96.4 & $6.73(\mathrm{~s})$ & 104.8 & $6.78(\mathrm{~s})$ & 92.4 \\
\hline $2 ", 6 ”$ & 128.3 & $7.59(\mathrm{~d}, 8.7)$ & 128.0 & $7.45(\mathrm{~d}, 8.8)$ & 127.8 \\
\hline $3 ", 5^{\prime \prime}$ & 116.0 & $6.74(\mathrm{~d}, 8.7)$ & 122.3 & $7.05(\mathrm{~d}, 8.8)$ & 115.4 \\
\hline \multicolumn{6}{|l|}{$\mathrm{CH}_{3}$} \\
\hline $\mathrm{MeO}-7$ & $56.1 *$ & $3.83(\mathrm{~s})$ & $56.0^{*}$ & $3.89(\mathrm{~s})$ & $56.5^{*}$ \\
\hline MeO-7" & $56.9 *$ & $3.86(\mathrm{~s})$ & $56.8 *$ & $3.93(\mathrm{~s})$ & $56.6 *$ \\
\hline $\mathrm{MeO}-5$ & - & - & - & - & $55.8 *$ \\
\hline $\mathrm{MeO}-5 "$ & - & - & - & - & $56.7 *$ \\
\hline $\mathrm{MeO}-4 "$ & - & - & - & - & $55.4^{*}$ \\
\hline$\underline{\mathrm{H}}_{3} \underline{\mathrm{CCO}} \mathbf{2}_{2}-4^{\prime \prime \prime}, 5 \underline{\mathrm{H}}_{3} \underline{\mathrm{CCO}}{ }_{2}-5 ”$ & -- & -- & $21.1,21.121 .1$ & $2.26(\mathrm{~s}), 2.41(\mathrm{~s}) 2.46(\mathrm{~s})$ & - \\
\hline $\mathrm{HO}-5,5^{2}, 4, "$, & - & $12.83,12.88,10.39(\mathrm{~s})$ & - & - & - \\
\hline
\end{tabular}

${ }^{\mathrm{a}} \mathrm{Homonuclear} 2 \mathrm{D}-{ }^{1} \mathrm{H}-{ }^{1} \mathrm{H}-\mathrm{COSY}$ spectra were also used in these assignments; *Values can be interchanged.

luteolin and 3-O-glycopyranosyl-quercetin were identified by ${ }^{1} \mathrm{H}$ and ${ }^{13} \mathrm{C}$ NMR spectral analysis of the natural substances and comparison of the data with values described in the literature. ${ }^{10,17-19}$ The ${ }^{1} \mathrm{H}-\left\{{ }^{1} \mathrm{H}\right\}$-NOE spectra resulting from irradiation of $\mathrm{H}-3,3$, 6" (in 2, 2a and 3) showed nOe of $\mathrm{H}-2$ ', 6', 2'", 6", $\mathrm{HO}-5$ " and $\mathrm{H}_{3} \mathrm{CO}-7$ ", in the respective structures; from irradiation of the methoxy groups (in 2, 2a) were detected NOE in the signals of H-6" (2 and 2a), H-3',5' and H-3'",5'" (2a). This information and the absence of NOE in the signals of $\mathrm{H}_{3} \mathrm{CO}$ - and of $\mathrm{HO}-$ 5 in the spectra from irradiation of $\mathrm{H}-8$ (in 2) confirmed the structures of these biflavonoids.

The IR spectrum of $\mathbf{1}$ exhibited absorption bands at $\max 3420 \mathrm{~cm}^{-1}(\mathrm{OH}), 1658 \mathrm{~cm}^{-1}$ (conjugated carbonyl) and 1600,1500 and $1440 \mathrm{~cm}^{-1}$ (aromatic ring). The peak at $\mathrm{m} / \mathrm{z} 566\left(2 \%, \mathrm{M}^{\circ}\right)$ observed in the LREIMS and the ${ }^{1} \mathrm{H}$ and
${ }^{13} \mathrm{C}(\mathrm{BBD}$ and DEPT) NMR spectral analysis was used to make the expanded molecular formula $(\mathrm{C}=\mathrm{O})_{2}$ $\mathrm{C}_{15}(\mathrm{CH})_{13}(\mathrm{OMe})_{2}(\mathrm{OH})_{3} \mathrm{O}_{3}=\mathrm{C}_{32} \mathrm{H}_{22} \mathrm{O}_{10}$. This formula is consistent with a biflavonyl ether skeleton with one free hydroxyl group $\left(\delta_{\mathrm{H}} 10.39\right)$, two H-bonded hydroxy groups $\left(\delta_{\mathrm{H}} 12.83\right.$ and 12.88$)$, two methoxy groups $\left(\delta_{\mathrm{H}} 3.83\right.$ and $3.86, \mathrm{~s}, 3 \mathrm{H}$ ), four doublets at $\delta_{\mathrm{H}} 8.06,7.59,7.17$ and 6.74 , corresponding to two AA'BB' systems in two parasubstituted aromatic rings, three singlets at $\delta_{\mathrm{H}} 6.94,6.85$ and 6.73 and two doublets $(2.0 \mathrm{~Hz})$ at 6.35 and 6.76 . The $\delta_{\mathrm{CH}}$ at 104.8, 104.2, 98.1, 96.4 and 92.8 are compatible with C-3, -3 ', $-6,-8$ and -6 '"of 1 . Comparison of the carbon chemical shifts of $\mathbf{1}$ with those of 7-methyllanaraflavone registered in the literature ${ }^{8}$ revealed the shielding of the methine carbons CH-6 (98.1), CH-8 (92.8), CH-6" (96.4) through a $\gamma$ effect of the carbon atom in the O-methyl group 

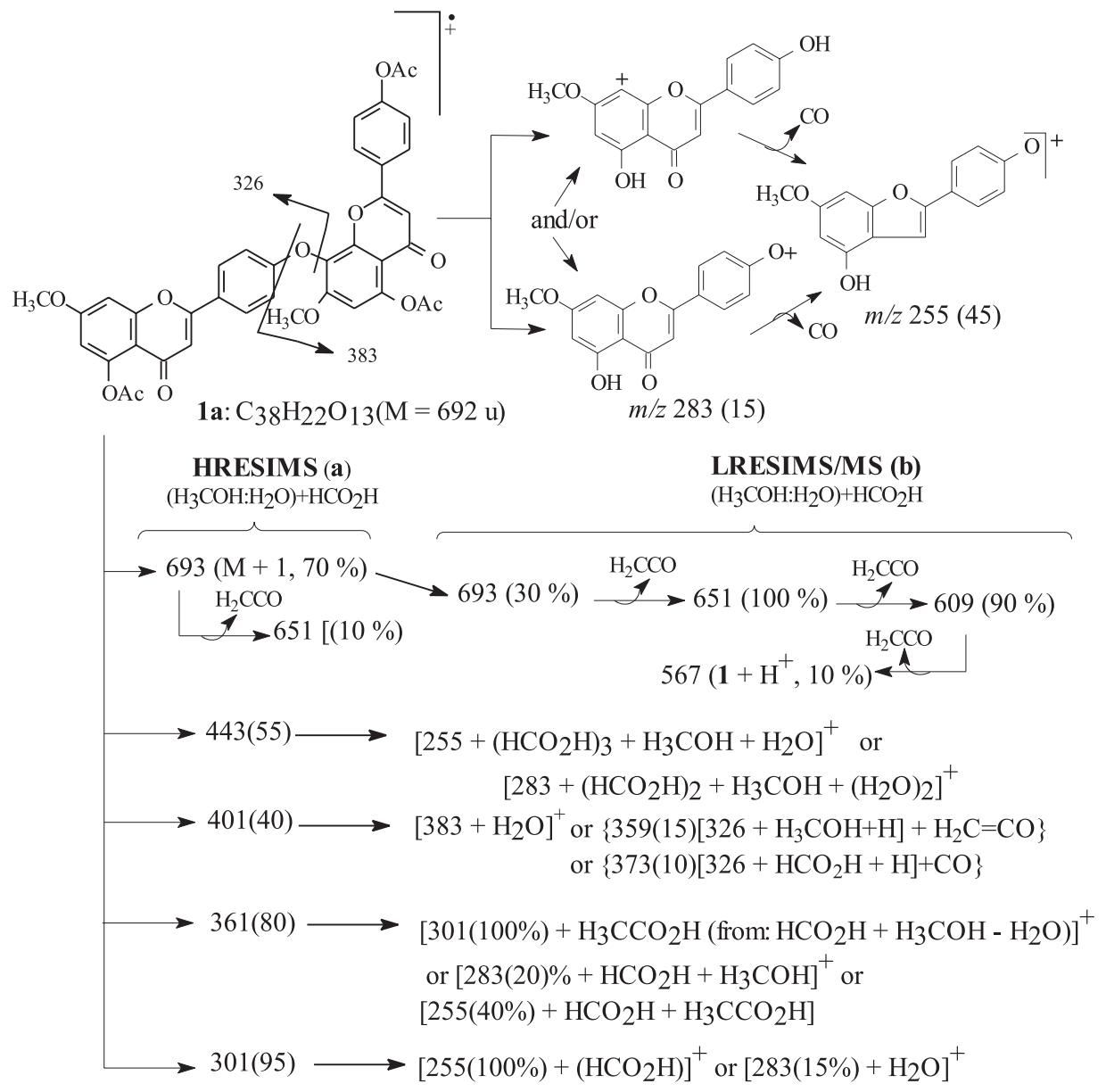

Scheme 1.

Table 2. ${ }^{1} \mathrm{H}\left\{{ }^{1} \mathrm{H}\right\}$-nOe difference spectral data of $\mathbf{1}\left(\mathrm{DMSO}_{\mathrm{6}}\right)$ and $\mathbf{1 a}\left(\mathrm{CDCl}_{3}\right)$

\begin{tabular}{|c|c|c|c|c|}
\hline \multicolumn{3}{|c|}{ Irradiation } & \multicolumn{2}{|c|}{ nOe } \\
\hline \multirow[t]{2}{*}{${ }^{1} \mathrm{H}$} & \multicolumn{2}{|c|}{$\delta_{\mathrm{H}}$} & \multicolumn{2}{|c|}{$\mathrm{H} ; \delta_{\mathrm{H}}(\%)$} \\
\hline & 1 & $1 \mathbf{a}$ & 1 & $1 \mathbf{a}$ \\
\hline $\mathrm{AcO}-4 "$, & - & 2.26 & & $3 ",, 5 ", ; 7.05(0.5)$ \\
\hline AcO-5 & - & 2.41 & - & $6 ; 6.59(0.5)$ \\
\hline $\mathrm{AcO}-5 "$ & - & 2.46 & - & 6"; 6.78(0.2) \\
\hline $\mathrm{MeO}-7$ & 3.83 & 3.89 & $6 ; 6.35(4.0) 8 ; 6.76(2.0)$ & $6 ; 6.59(11.0) 8 ; 6.84(13.0)$ \\
\hline MeO-7" & 3.86 & 3.93 & $6 " ; 6,73(5.0)$ & $6 " ; 6.78(10.0)$ \\
\hline 3 & - & 6.52 & - & $2^{\prime}, 6^{\prime} ; 7.82(20.0)$ \\
\hline $3 "$ & - & 6.54 & - & $2 ", 6 ", ; 7.45(25.0)$ \\
\hline
\end{tabular}

at C-7 and C-7'. The absence of additional signal of $\mathrm{CH}$ near $93.0 \mathrm{ppm}$ indicated that $\mathrm{C}-8$ is involved in the connection of the flavonoid moieties. The ${ }^{1} \mathrm{H}\left\{{ }^{1} \mathrm{H}\right\}$-nOe difference spectra of $\mathbf{1}$ with irradiation at 3.86 showed nOe at $\delta_{\mathrm{H}} 6.73(\mathrm{~s})$ and irradiation at 3.83 showed NOE at 6.76(d, $2 \mathrm{~Hz}$ ) and 6.35 (d, $2.0 \mathrm{~Hz}$ ) (Table 2). The LRESIMS-MS (negative mode) of ion with $\mathrm{m} / \mathrm{z} 565(40 \%)$ yields peaks at
$550(60 \%), 283(100 \%)$ and $255(50 \%)$ that are in agreement with dimethoxylanaraflavone. These information along with the absence of a nOe on the doublets for H-3',5" and 3"', 5" confirmed the location of the methoxy group at 7 and 7"' and also the 4'-O-8 connection. The homonuclear 2D ${ }^{1} \mathrm{Hx}{ }^{1} \mathrm{H}$-COSY was used to make the chemical shift assignment of $\mathbf{1}$ (Table 1). The analysis of $2 \mathrm{D}^{1} \mathrm{Hx}^{1} \mathrm{H}-\mathrm{COSY}$ 
and ${ }^{1} \mathrm{H}\left\{{ }^{1} \mathrm{H}\right\}$-nOe difference spectra (Table 2) together with the peaks at $m / z(\%) 693.1554\left[\mathrm{M}^{+\bullet}+1,70 \%\left(\mathrm{C}_{38} \mathrm{H}_{22} \mathrm{O}_{13}+\right.\right.$ $\left.\mathrm{H}^{+}\right)$], 443 (55), 401 (40), 361 (80) and 301 (95) in the HRESIMS (positive mode, Scheme-1) of the acetyl derivative (1a) corroborates the dimethoxylanaraflavone structure. Irradiation at $3.89\left(\mathrm{H}_{3} \mathrm{CO}-7\right)$ yields an $\mathrm{NOE}$ at $\delta_{\mathrm{H}}$ $6.59(\mathrm{H}-6)$ and $6.84(\mathrm{H}-8)$ and irradiation at $3.93\left(\mathrm{H}_{3} \mathrm{CO}-\right.$ 7") afforded NOE at 6.78 (H-6"). The nOe observed at the chemical shifts of H-3" ",5", H-6" and H-6 with irradiation at $\underline{\mathrm{H}}_{3} \mathrm{CCO}$ (in 1a) confirmed the location of three hydroxy groups at 4", 5 " and 5 in the natural biflavone 1. Additional NOE observed at the doublet of H-2',6' and of H-2,", 6', by irradiation at H-3 and H-3" (Table 2) and the cross peaks in the ${ }^{1} \mathrm{Hx}^{1} \mathrm{H}-\mathrm{COSY}$ of $\mathbf{1 a}$ were used to make the complete hydrogen chemical shifts assignments (Table 1). The LRESIMS-MS (positive mode) spectra of the ion with $\mathrm{m} / \mathrm{z}$ 693 allowed us to confirm the three acetyl group with peaks at $m / z$ (\%): 651 (100), 609 (90) and 567 (10). The same analysis was made with ions (set of species: fragment of 1a, formic acid, methanol and water) at $\mathrm{m} / \mathrm{z} 443,401$, 361 and 301 to identify the peaks of $1 \mathbf{a}$ with $\mathrm{m} / \mathrm{z}$ 383, 326, 283 and 255 (Scheme 1). Treatment of $\mathbf{1}$ with dimethylsulfate gave the penta-O-methyl derivative (1), mp $265{ }^{\circ} \mathrm{C}$ ) with the same ${ }^{1} \mathrm{H}$ NMR chemical shifts registered in the literature ${ }^{16}$. Thus, it was possible to confirm the structure of the new lanaraflavone derivative (1) and to make the complete carbon-13 chemical shift assignment of the pentamethyl derivative $\mathbf{1 b}$, which has not been previously reported (Table 1).

\section{Acknowledgements}

The authors are grateful to CNPq, CAPES and FAPERJ for scholarships and financial support.

\section{References}

1. Heywood, V.H.; Flowering Plants of the World, Oxford University Press: London, 1978, p. 82.

2. de Carvalho, M.G.; de Oliveira, M.C.C.; Werle, A.A.; J. Braz. Chem. Soc. 2000, 11, 232.

3. de Oliveira, M.C.C.; de Carvalho, M.G.; da Silva, C.J.; Werle, A.A.; J. Braz. Chem. Soc. 2002, 13, 119.
4. de Carvalho, M.G.; Alves, C.C.F.; da Silva, K.G.S.; Eberlin, M.N.; Werle, A.A.; J. Braz. Chem. Soc. 2004, 15, 146.

5. de Carvalho, M.G.; de Carvalho, G.J.A.; Braz-Filho, R.; J. Braz. Chem. Soc. 2000, 11, 143.

6. Velandia, J.R.; de Carvalho, M.G.; Braz-Filho, R.; Quim. Nova 1998, 21, 397.

7. Velandia, J.R.; de Carvalho, M.G.; Braz-Filho, R.; Nat. Prod. Lett. 1998, 12, 191.

8. Velandia, J.R.; de Carvalho, M.G.; Braz-Filho, R.; Werle, A.A.; Phytochem. Anal. 2002, 13, 283.

9. Moreira, I.C.; Sobrinho, D.C.; de Carvalho, M.G.; Braz-Filho, R.; Phytochemistry 1994, 35, 1567.

10. Moreira, I.C.; de Carvalho, M.G.; Bastos, A.B.F.O.; Braz-Filho, R.; Phytochemistry 1999, 51, 833.

11. de Carvalho, M.G.; Velandia, J.R.; de Oliveira, M.C.C.; Echevarria, A.; Braz-Filho, R.; Grynberg, N.F. In Phytochemical and Pharmacology II of the Series "Recent Progress in Medicinal Plants", Majumdar, D.K.; Govil, J.N.; Singh, V.K. eds., SCI Tech Publishing LLC: Texas, USA, 2002, 8, p.77-92.

12. Grynberg, N.F.; de Carvalho, M.G.; Velandia, J.R.; de Oliveira, M.C.C.; Moreira, I.C.; Braz-Filho, R.; Echevarria, A.; Braz. J. Med. Biol. Res. 2002, 15, 819.

13. Felicio, J.D.; Gonzalez, E.; Braggio, M.M.; Constantino, L.; Albasini, L.A.; Lins, A.; Planta Med. 1995, 61, 217.

14. Cortes, F.S.; Barbosa, M.P.T.; Braga, A.O.; Braga, F.C.; Lemos, S.V.; Valadares, M.Y.; Planta Med. 2002, 68, 412.

15. Castro, F.B.; Braga, A.O.; Lombardi, J.A.; Wagner, H.; Phytomedicine-Jena 2000, 7, 245.

16. Dora, G.; Edwards, J.M.; J. Nat. Prod. 1991, 54, 796.

17. Chari, V.M.; Chen, F.; Chen, L.; Ilyas, M.; Lin, Y.C.; Lin, Y.M.; Neszmély, A.; Wagner, H.; Phytochemistry 1977, 16, 1273.

18. Agrawal, K.P.; Bansal, M.C.; Porter, L.J.; Foo, L. Y.; Flavonoid Glycosides and Agrawal, K.P.; Bansal, M.C.; Flavonoids In Carbon-13 NMR of Flavonoids; Agrawal P.K., ed., Elsevier: New York, USA, 1989, p. 283-364 and 432-496.

19. Kardono, L.B.S.; Tsauri, S.; Padmawinata, K.; Kinghorn, A.D.; Phytochemistry 1990, 29, 2995.

Received: March 2, 2004

Published on the web: March 4, 2005

FAPESP helped in meeting the publication costs of this article. 